\title{
Comparable Worth in the Equal Pay Act -
}

\author{
Mayer G. Freed $\dagger$ \\ Daniel D. Polsby $\dagger \dagger$
}

The idea of "equal pay for work of comparable value," or "comparable worth," has received much attention in recent years." It has been called the "women's issue of the 80 's," and at least one federal district court apparently adopted the theory when it ordered a large government employer to completely restructure its workforce. $^{3}$

According to the theory of "comparable worth," jobs that are held largely by women are systematically undervalued in the labor market as compared with jobs held largely by men. This systematic undervaluation can be uncovered by measuring the relative values of jobs as disparate as, say, schoolteacher and truck driver, according to objective standards. For example, both jobs can be analyzed according to training required, effort expended, responsibility entailed, and working conditions endured. Even if one job requires more effort, the other job may be equally valuable because it requires more training or because it is performed under less desirable working conditions. ${ }^{4}$

$\dagger$ Professor of Law, Northwestern University.

If Professor of Law, Northwestern University.

1 "Comparable worth" as used in this paper means the theory that people who perform jobs that, while dissimilar (e.g., truckdrivers and infirmary nurses), have a comparable economic value to employers ought to be paid equal wages. Some proponents of the comparable-worth theory claim that it can be read into the nondiscrimination mandate of Title VII of the Civil Rights Act of 1964,42 U.S.C. $\$ \S 2000$ e to 2000 e-17 (1982). See, e.g., Comment, Equal Pay, Comparable Work, and Job Evaluation, 90 YALE L.J. 657, 670 (1981) (arguing that "Title VII's broad proscription of discriminatory compensation practices" requires equal pay for comparable work). No one, however, seems to believe that anything like a recognizable "Iegislative intent" is a part of the theory's pedigree. See, e.g., International Union of Elec. Workers, Local 449 v. Westinghouse Elec. Corp., 631 F.2d 1094, 1101-05 (3d Cir. 1980); Williams \& McDowell, The Legal Framework, in Comparable Worth: Issues and Alternatives 197, 212, 224 (E. Livernash ed. 1980).

2 DaIty Labor RePorts (BNA) 211 (Oct. 30, 1979) (statement by EEOC Commissioner Eleanor Holmes Norton).

3 American Fed'n of State, County \& Mun. Employees v. Washington, 578 F. Supp. 846 (W.D. Wash. 1983).

4 See generally Livernash, An Overview, in Comparable Worth: Issues and Altzrnatives 1, 8-10 (E. Livernash ed. 1980); Michael Gold, A Dialogue on Comparable Worth 28-54 (1983); Women, Work, and Wages: Equal Pay ror Jobs of Equal Value 56-67 (D. 
There is widespread agreement in the courts that comparable worth may not be seriously entertained as a basis for liability under Title VII of the Civil Rights Act of $1964 .^{\circ}$ By contrast, courts have accepted the notion that the mandate of "equal pay for equal work" under the federal Equal Pay Act of 1963 may be extended to reach work situations that are not strictly "equal." It is our purpose in this paper to examine what is actually entailed in implementing the principle of "equal pay for equal work." We will show that, far from being an uncontroversial proposition with none of the problems attendant on the theory of comparable worth, it is a slogan that, in practical implementation, raises many of the same issues.

The prohibition on paying men and women unequal wages for

Treiman \& H. Hartmann eds. 1981). The theory of comparable worth has been a subject of lively debate in scholarly works, journals of opinion, and the political arena. See, e.g., Barnett, Comparable Worth and the Equal Pay Act-Proving Sex-based Wage Discrimination Claims After County of Washington v. Gunther, 28 WAYNE L. REv. 1669 (1982); Blumrosen, Wage Discrimination, Job Segregation, and Title VII of the Civil Rights Act of 1964, 12 U. Mich. J.L. REF. 399 (1979); Bunzel, To Each According to Her Worth?, 67 PuB. INTEREST 77 (1982); Cox, Equal Work, Comparable Worth and Disparate Treatment: An Argument for Narrowly Construing County of Washington v. Gunther, 22 DuQ. L. Rev. 65 (1983); Levin, Comparable Worth: The Feminist Road to Socialism, Commentary, Sept. 1984, at 13; Smith, The EEOC's Bold Foray into Job Evaluation, ForTune, Sept. 11, 1978, at 58; N.Y. Times, Feb. 17, 1984, at A30, col. 1; Wall St. J., Sept. 15, 1981, at 28. Critics of the theory of comparable worth question the notion that the average earnings gap between men and women is attributable to sex discrimination in the market; further, they lament the fact that the theory of comparable worth "rejects the market" as a method of determining value; finally, they claim that any attempt to objectify the wage-setting process is impracticable. See, e.g., Cox, supra, at 85-90; Livernash, supra, at 8-14; Milkovich, The Emerging Debate, in Comparable Worth: Issues and AltzRnatives 23, 36-38 (E. Livernash ed. 1980).

B 42 U.S.C. $\$ \S 2000$ e to 2000 e-17 (1982); see Lemons v. City \& County of Denver, 620 F.2d 228, 229 (10th Cir.), cert. denied, 449 U.S. 888 (1980); Brennan v. City Stores, Inc., 479 F.2d 235, 238 (5th Cir. 1973); Francoeur v. Corroon \& Black Co., 552 F. Supp. 403, 406-07 (S.D.N.Y. 1982).

- See, e.g., Thompson v. Sawyer, 678 F.2d 257, 271-72 (D.C. Cir. 1982) (discussing the "substantially equal" test). The Equal Pay Act, 29 U.S.C. § 206(d) (1982), provides in pertinent part:

(d) Prohibition of sex discrimination

(1) No employer having employees subject to any provisions of this section shall discriminate, within any establishment in which such employees are employed, between employees on the basis of sex by paying wages to employees in such establishment at a rate less than the rate at which he pays wages to employees of the opposite sex in such establishment for equal work on jobs the performance of which requires equal skill, effort, and responsibility, and which are performed under similar working conditions, except where such payment is made pursuant to (i) a seniority system; (ii) a merit system; (iii) a system which measures earnings by quantity or quality of production; or (iv) a differential based on any other factor other than sex: Provided, That an employer who is paying a wage rate differential in violation of this subsection shall not, in order to comply with the provisions of this subsection, reduce the wage rate of any employee. 
"equal" work is most clearly applicable to a case of sex discrimination with "clean" facts: an employer who has two employees, $M$ and $F$, each assigned to identical jobs and each indistinguishable from the other in terms of qualifications and performance, chooses to pay $F$ a lower wage than $M$ solely because $F$ is a woman. In this prototypical situation, there is no question that the employer has violated the Equal Pay Act. We do not know, however, of an Equal Pay Act case involving such prototypical facts. Such cases certainly must arise, but as a practical matter they are undoubtedly settled before litigation. The cases that are brought to trial diverge in one or more respects from the prototype. For example, direct evidence of the employer's motivation is typically unavailable, or two jobs claimed to be "substantially equal" for statutory purposes will often differ in certain respects. Furthermore, no two employees are identical in every way, however similar their jobs may be. Introducing any of these variations from the prototypical case will raise questions about the appropriateness of treating such a variant case like the prototype.

In cases that diverge from the prototype, two main sorts of problems will arise. First, absent direct evidence that the employer paid a man and a woman different wages because of sex-by "direct evidence" we have in mind "smoking gun" statements by the employer-a case resembling the prototype can only be established by inferences, drawn from the surrounding circumstances, about the employer's motives or reasons for paying a different wage. Second, even if the employer's motives were not based on the sex of the employees, a violation of the Equal Pay Act might still be found if the proffered reasons for paying $M$ and $F$ different wages-reasons relating to supposed differences either in the job or in the people who perform the job-were thought inadequate to "justify" the difference.

In the sections that follow, we explore the ways in which courts attempt to address these questions. In Parts I, II, and III, we use hypothetical fact situations to clarify the particular issues that may arise in an Equal Pay Act case. Our discussion is intended to focus attention on the many ways in which those properties of the theory of "comparable worth" that have engendered criticism are already and inevitably involved in the practical administration of the Equal Pay Act. Part I discusses the proposition that "the market" is the problem for which the Equal Pay Act is

7 Courts have interpreted the Equal Pay Act to require not that jobs be identical, but only that they be "substantially equal." See infra note 13 and accompanying text. 
the solution. Part II considers the methods available to a court in determining when nonidentical jobs are similar enough to fall within the ambit of the Equal Pay Act. Part III examines the circumstances under which an employer may be able to justify the payment of different wages to persons performing "equal work" under the statute. Part IV considers some of these problems as they arise in relation to one another in decided cases.

\section{Rejection of the Market}

The basic premise of the Equal Pay Act is that the labor market is in need of regulation because of a serious imperfection: the market's undervaluation of women's labor. ${ }^{8}$ Thus, the Equal Pay Act "rejects the market" as an explanation or justification of unequal pay for equal work, as the following discussion illustrates.

\section{Hypothetical 1}

An advertising agency, overloaded with work, seeks to hire two new account executives. The boss has determined that, if suitable people can be found, she can afford to spend as much as $\$ 100,000$ to fill both positions, but she would, of course, prefer to spend as little as possible. After conducting many interviews, the boss's two prime candidates are $M$ (a male) and $F$ (a female). As far as anyone, including the boss, can see, $M$ and $F$ have more or less indistinguishable credentials for the position. They both graduated at the top of their classes from good colleges, they are the same age, and they have similar experience and work records. In pursuit of the goal of paying less rather than more, the boss offers accountexecutive positions to both $M$ and $F$ at a salary of $\$ 42,000$ per year. $F$ accepts on the spot; $M$, however, asks for a higher salary, and, after further negotiation, $M$ and the boss agree on an annual salary of $\$ 50,000$.

If the boss decides not to raise $F$ 's salary to $\$ 50,000$ after $M$ has successfully bargained for this higher rate, and if $M$ and $F$ perform nearly identical services for the advertising agency at these different salaries, has the Equal Pay Act been violated?

- See, e.g., Corning Glass Works v. Brennan, 417 U.S. 188, 195 (1974) (the purpose of the Equal Pay Act was to remedy "what was perceived to be a serious and endemic problem of employment discrimination in private industry-the fact that the wage structure of 'many segments of American industry has been based on an ancient but outmoded belief that a man, because of his role in society, should be paid more than a woman even though his duties are the same' ") (quoting S. RkP. No. 176, 88th Cong., 1st Sess. 1 (1963)). 
There seems to be little question that a violation will have occurred. By the terms of the hypothetical, the boss can point to no objective difference in the credentials or abilities of $M$ and $F$. Moreover, the example also assumes that the two account-executive positions are not materially different as far as working conditions or the skill, effort, and responsibility necessary to their performance are concerned. The boss's only explanation for the salary difference is that $F$ was willing to work for less money than was $M$ and that the boss, for economic reasons, was willing to go along. ${ }^{9}$

Holding the employer liable in this situation amounts to a rule of strict liability, in the sense that the employer's liability derives from the difference in wages, even if there is no showing that sex was a factor, either consciously or unconsciously, in the employer's decision. Of course, it is possible that the boss was either consciously or unconsciously influenced by the sex of the prospective employee. We might believe, for example, that if it had been $M$ who had accepted the lower salary while $F$ had held out for more, the employer would then have automatically raised M's salary. Even if there were no evidence on this point, however, and even if a court believed that the boss's subjective motivation was not tainted by considerations of sex, it appears that the boss would still be liable. ${ }^{10}$ The employer's assertion that she was merely paying the bargained-for "market" rate will not help in an Equal Pay Act claim. ${ }^{11}$ As courts have noted, the Equal Pay Act is a statute

- Many employers faced with this situation would react differently than our hypothetical boss did and would for a variety of reasons choose to pay $F \$ 50,000$ even though she had accepted the offer of $\$ 42,000$. A number of managers to whom we have spoken indicate that they would raise F's salary to $\$ 50,000$ in order to avoid the morale problems that they believe would follow from inequalities of compensation not based on merit. But not all managers would react this way. Whether envy will result from a difference in treatment depends upon whether employees know the salaries of their coworkers. Moreover, any particular manager might believe that the costs of envy are more than made up for by the savings achieved by paying employees as little as possible. If the boss decides for these or other reasons to maintain the differential, the Equal Pay Act will have been violated, and the remedy for this violation will be to raise F's salary to $\$ 50,000$. See 29 U.S.C. $\S 206$ (d)(1) (1982).

${ }^{10}$ See Strecker v. Grand Forks County Social Serv. Bd., 640 F.2d 96, 99 n.1 (8th Cir. 1980); see also Brennan v. Victoria Bank \& Trust Co., 493 F.2d 896, 898 (5th Cir. 1974) (the plaintiff need only show "unequal pay for jobs of equal work and responsibility"); Futran v. Ring Radio Co., 501 F. Supp. 734, 738 (N.D. Ga. 1980) (Equal Pay Act prohibits an employer from paying different wages to employees of opposite sexes for substantially equal work); Di Salvo v. Chamber of Commerce, 416 F. Supp. 844, 853 (W.D. Mo. 1976) (" $[E]$ vidence that plaintiff"s male successor, who performed the same duties, was paid a higher salary then plaintiff is sufficient to prove discrimination in compensation because of sex."), aff'd in part, modified in part on other grounds, 568 F.2d 593 (8th Cir. 1978).

${ }^{11}$ See, e.g., Brennan v. Victoria Bank \& Trust Co., 493 F.2d 896, 901-02 (5th Cir. 1974); 
whose very purpose is to overcome sex discrimination that is assumed to exist in the employment market. ${ }^{12}$

What does it mean to say that the market discriminates, and how does that assertion bear on our hypothetical? Why was $F$ willing to accept a $\$ 42,000$ offer while $M$ was not? It may be that $M$ had an offer from another advertising agency for a job paying more than $\$ 42,000$. $F$ may have had no other offer at all, or may have had other offers that were no higher than our boss's offer. If this fact explains $F$ 's willingness to work for $\$ 42,000$ (or M's unwillingness to work for that amount), and if one believes that $M$ 's ability to garner better offers than $F$ is symptomatic of some underlying sex discrimination by other employers, this situation presents an instance of discrimination by the market itself.

But "market discrimination" is not the only imaginable explanation for the differing bargaining outcomes. Suppose the advertising agency is located in Chicago. If $F$ is from Chicago, while $M$ is from San Diego, it would not be surprising if $M$ demanded a "combat pay" differential for which $F$, accustomed to the harsh climate, did not feel the need. Maybe the difference in pay was related to the fact that $M$ is married, with two children and a hefty new mortgage, while $F$ is single and has a substantial income from the family trust fund. These two differences are clearly not the results of a discriminatory employment market.

The case just recounted does not appear to stir up the civilrights sensibilities of many proponents of the "equal pay for equal work" principle. But if we vary the hypothetical superficially, it begins to look much more like a mainstream civil-rights problem.

\section{Hypothetical 2}

Instead of offering $\$ 42,000$ to both $M$ and $F$, the boss initially offers $M \$ 50,000$ and $F \$ 42,000$, and they both accept. The boss's reason for making different offers is not the sex of the two employees, but rather that the boss is acquainted with one or more of the factors that we have described above. She knows that $M$ has competing offers in excess of $\$ 42,000$, and that $F$ does not; or she knows that $M$ is partial to warm climates, and that $F$ likes Chicago for a variety of reasons; or she

Brennan v. City Stores, Inc., 479 F.2d 235, 241 n.12 (5th Cir. 1973); Futran v. Ring Radio Co., 501 F. Supp. 734, 739-40 (N.D. Ga. 1980); Di Salvo v. Chamber of Commerce, 416 F. Supp. 844, 853 (W.D. Mo. 1976), aff'd in part, modified in part on other grounds, 568 F.2d 593 (8th Cir. 1978).

12 See supra note 8 and accompanying text. 
knows that $M$ has a number of financial burdens that $F$ does not have. Moreover, the boss believes that getting to the bottom line as soon as possible, as opposed to extended dickering over salary, is conducive to a constructive employment relationship.

This second hypothetical presents an intuitively stronger case for finding a violation of the Equal Pay Act because one senses that, in the first case, the employer indicated her nondiscriminatory good faith by making equal initial offers to $M$ and $F$. In the second case, the fact that the boss made a higher offer to $M$ may leave us with more uncertainty about her motives: here it is more likely that she was in fact simply willing to pay more for a man than for a woman. Moreover, in the first case we appear to have more information about the "real" price of $M$ 's services because the $\$ 50,000$ salary is the outcome of a process of bargaining, while in the second case it merely represents the boss's estimate of the right price. For all we know, $M$ would have accepted an offer of $\$ 45,000$, and the extra $\$ 5000$ is a kind of windfall to him.

But the two hypotheticals are essentially identical. While the first case appears to be an instance in which the outcome does not smack of discriminatory conduct by the employer, we can hardly be sure this is the case. First, the boss might have preferred all along to pay men more than equally qualified women and would have been unwilling to pay $F$ more than $\$ 42,000$ if $F$, rather than $M$, had held out. In fact, if the boss was aware of any of the factors that would influence $F$ to accept a lower salary, the boss might have initially offered equal salaries merely to give the appearance of equal treatment in the opening round of a negotiating process that she actually expected would result in unequal salary outcomes. Second, by offering the same salary to two people who (leaving their sex to one side) do not seem to the employer to be equally desirable employees, an employer subjectively discriminates just as much as when making unequal offers to people who are equal in the eyes of the employer. The boss's initial offers of $\$ 42,000$ to both $M$ and $F$ might therefore have been discriminatory in the sense that the boss would have been willing to offer $M$ only $\$ 38,000$ had he been female or $F$ as much as $\$ 46,000$ had she been male.

Moreover, the greater apparent uncertainty concerning the "real" salary of $M$ in Hypothetical 2-where the salary was not the result of bargaining-is illusory. Obviously the employer who initially offers $M \$ 50,000$ will never know whether $M$ would have accepted less. But this sort of uncertainty is also present where the 
salary is bargained for. Suppose the boss offers $M \$ 42,000$, and $M$ refuses. The boss offers $\$ 47,000$, and $M$ refuses yet again. Finally, the boss offers $\$ 50,000$, and $M$ accepts. We cannot know whether $M$ would have accepted some salary greater than $\$ 47,000$, but less than $\$ 50,000$, for the same reasons that we cannot know whether $M$ would have accepted less than $\$ 50,000$ in the second hypothetical. Furthermore, although the point is easy to overlook or assume away, there is a similar uncertainty about $M$ 's willingness to accept an offer between $\$ 42,000$ and $\$ 47,000$. M's rejection of the $\$ 42,000$ offer does not necessarily indicate that he would not work for $\$ 42,000$; it may also indicate that he believes that indicating an unwillingness to work for $\$ 42,000$ will result in his getting a somewhat higher salary. For all we know, if the boss had told $M$ that $\$ 42,000$ was her final offer, $M$ would have capitulated. Indeed, we cannot know for sure whether $M$ will accept any given salary offer before agreement is reached. Even then, we know only that $M$ has accepted a wage equal to or greater than the minimum he is willing to accept (in economic terms, his "market wage," or next-best alternative).

As a final note, it may seem that rejection of the market in the limited context of the Equal Pay Act is free from the major objection to the theory of "comparable worth"- that in the absence of markets, there is no way to determine the value of labor, either absolutely or relatively. One might conclude that, in the Equal Pay Act context, the wage actually paid by the employer to the more highly paid sex-usually men-represents the job's "objective" value. But this argument is valid only if one assumes that the jobs are identical and the employees indistinguishable; as these assumptions are relaxed, it becomes more difficult to compare two different jobs occupied by two different employees and conclude that the wage paid in one case is also the correct wage in the other. As we will see, when courts are faced with Equal Pay Act cases involving nonidentical jobs and nonidentical workers, they must necessarily employ the same imaginative leaps that they would need to employ under a theory of "comparable worth."

\section{Equal/Unequal Jobs}

\section{A. Job Content}

So far, we have assumed in our advertising-agency hypothetical that the two positions the boss is seeking to fill are identical. We now introduce the notion of nonidentical jobs. 


\section{Hypothetical 3}

$M$ and $F$ are currently employed by the agency as account executives, and each is responsible for the creative design of advertising campaigns, as well as for day-to-day dealings with his or her particular clients. In addition to account executives, the agency employs production executives, who are required to implement campaigns designed by the account executives, secure advertising space, coordinate special events, and arrange publicity. The salaries of $M$ and $F$ as account executives are $\$ 50,000$ per year, and the agency hires entry-level production executives at a salary of $\$ 50,000$ per year. The boss now sees the need for some additional staffing on the production side, but feels that current needs do not justify hiring a fulltime production executive. Consequently, the boss wishes to modify the functions of one of her account executives by assigning production responsibilities, in lieu of account responsibilities, on an "as needed" basis. The combined account/production job will be no more arduous than either the account executive or production executive job; it will just be different. The boss decides that the person assigned the new responsibilities will receive a $\$ 10,000$ raise over the account-executive salary of $\$ 50,000$ and asks $M$ and $F$ whether one of them will accept the new account/production job. $F$ expresses complete disinclination to accept this proposal, and $M$ accepts on the spot. In the first year of working under the new system, $M$ spends fifteen percent of his time on production duties and eighty-five percent of his time performing account duties.

For the employer to be in violation of the Equal Pay Act, $F$ 's job as an account executive must be considered "equal" to $M$ s account/production job. Manifestly, the two jobs are not identical, and a court asked to decide whether they are "equal" under the Act will have to exercise some judgment. Broadly speaking, the issue is whether there is a sufficient similarity between the jobs to justify treating this case like the prototypical Equal Pay Act case that involves truly identical jobs.

Acknowledging that any two jobs are rarely identical and assuming that the Equal Pay Act was meant to require more than equal pay for only "perfectly equal" jobs, the courts have developed the standard of "substantial equality." Unfortunately, this

13 See, e.g., Shultz v. Wheaton Glass Co., 421 F.2d 259, 265 (3d Cir.), cert. denied, 398 U.S. 905 (1970); see also 29 C.F.R. $\$ 800.120$ (1983) ("There is evidence that Congress in- 
formula presupposes some standard against which to measure the similarity of the jobs without indicating what that standard might be.

Given the statute's concern with sex discrimination, ${ }^{14}$ one might address the job-equality issue by asking whether the differences between the two jobs were merely a pretext or excuse for paying men and women differently. Alternatively, one could ask whether the employer's decision to compensate the two jobs differently was "reasonable." As it turns out, it is unnecessary to choose between these two approaches because, in this context at least, each requires essentially the same analysis. In the absence of "smoking gun" evidence, a court will be able to decide whether the difference in the two jobs is merely a pretext for illicit discrimination only by asking whether, in the absence of discrimination, the employer would have paid incumbents of the two jobs differently; the only intelligible procedure by which to answer this question is to evaluate the employer's conduct against some standard of reasonableness. But in order for a court to evaluate an employer's decisions concerning the appropriate wage rates for various jobs, there must be something like an objective and intrinsic value to a given job, apart from what employers are willing to pay for the performance of the job.

How might a court determine whether, in Hypothetical 3, $M$ and $F$ are performing substantially equal work? If what we have just said is correct, a court will have to decide whether it is reasonable for the employer to pay $M$ more for the job he is performing than $F$ is paid for the job she is performing. Generally, market transactions are assumed to be self-validating on the question of valuation: the sum upon which the employer and employee can agree is, for lack of a better definition, the value of the employee's services. If market valuation is an unacceptable standard, however, other criteria must be found to judge the reasonableness of the agreed-upon wage. Specifically, one must either examine the reasons actually given by the employer for the pay disparity or imagine what good reasons there might be for one, whether or not the employer actually proffers them. Unfortunately, performing this task fairly is close to impossible.

tended that jobs of the same or closely related character should be compared in applying the equal pay for equal work standard.").

14 The Equal Pay Act does not, for example, prohibit an employer from paying two men different wages even for identical jobs, let alone for jobs that are only "substantially equal." See 29 U.S.C. § 206(d)(1) (1982) (prohibiting discrimination "on the basis of sex"). 
Suppose the boss says that increasing the flexibility of the work force and leveling out the work load of employees increases the efficiency of the enterprise as a whole. The ability to assign spillover production work to $M$ without the necessity of hiring a new, full-time production executive is, in the boss's view, the best way to maximize overall productivity. Of course, the mere fact that having someone available to perform the combined account/production job increases the overall efficiency of the enterprise does not automatically mean that all the efficiency gains should be attributed to the employee performing the combined job. If the boss was willing to pay $\$ 10,000$ extra to a work force in which one employee performs only account-executive functions while a second performs combined functions, why not disburse that extra $\$ 10,000$ by paying each employee $\$ 5000$ extra? The employer might reply that some differentiation of the two jobs is necessary in order to induce one of the employees to accept production responsibilities. But even if we were willing in principle to accept this as a justification, it would often be impossible to know that any differential was in fact necessary as an inducement, let alone the $\$ 10,000$ offered. ${ }^{16}$

It could also be argued that the employer could have assigned combined duties to both account executives and given them each a $\$ 5000$ raise. The employer might prefer not to do so for any number of reasons: it might be more costly to supervise two people in this new job than to supervise one; giving both employees combined duties might be inconsistent with the employer's belief that on the whole it is more efficient to have employees specialize; or spillover production work may be insufficient to allow two people to develop production expertise soon enough.

The employer may face still more difficulties. What if the production-only executives were paid $\$ 45,000$ rather than $\$ 50,000$ ? In such a situation, a court might think that the lower pay of production-only executives undermines the assertion that the employer had to pay $M$ a premium over his $\$ 50,000$ account-executive salary to induce him to accept production duties. ${ }^{16}$ But it is hard to see

15 See supra pp. 1084-85 (discussing uncertainty about the lowest wage at which employee would in fact have agreed to work).

16 See, e.g., Brennan v. Prince William Hosp. Corp., 503 F.2d 282, 286 (4th Cir. 1974), cert. denied, 420 U.S. 972 (1975); Shultz v. American Can Co.-Dixie Prods., 424 F.2d 356, 360-61 (8th Cir. 1970); Shultz v. Wheaton Glass Co., 421 F.2d 259, 263 (3d Cir. 1970), cert. denied, 398 U.S. 905 (1970); cf. EEOC Proposed Equal Pay Act Interpretations, 46 Fed. Reg. 43,848, 43,851 (1981) (to be codified at 29 C.F.R. § 1620.8) (additional duties may not be a defense to the payment of higher wages to one sex where the higher pay is not related to the extra duties). 
why. As long as the employer believes that the gains to be realized from the flexibility of a combined account/production job exceed the salary increase, it would not be surprising that the employer was willing to pay more for a combined job than she was willing to pay for either of the jobs separately. ${ }^{17}$

If we vary the hypothetical involving the account/production executive a bit more, new complications arise. Suppose there are a number of male and female account/production executives and that, although an account/production executive spends on average fifteen percent of his time on production work, in fact the amount of time spent on production by any one of these employees will vary between five percent and twenty-five percent of the employee's total working hours. In such a case, a court may decide that the employer's rationale for the pay differential-that the production work performed by these account/production executives renders them more valuable than the pure account executives-is undercut by the failure of the employer to distinguish between the account/production executives on the basis of the amount of production work performed by each of them. ${ }^{18}$ In effect, the objection is that it is unreasonable for an employer to pay a standard wage rather than a piecework rate. Once again, there is little basis for this view. While some employers may prefer piecework compensation for one reason or another, other employers could just as persuasively assert that the morale of employees will be enhanced by a steady, predictable income, especially where opportunities to perform the tasks for which piecework compensation will be paid may vary considerably over time and among employees.

Finally, in evaluating the reasonableness of an employer's de-

17 One could also tell equally plausible stories to justify or explain an employer's actions if the employer decided to pay both employees the same salary or if the employer decided to pay the pure account executive a higher salary than the employee performing the combined account/production job. For example, there might be gains to morale if all executives were paid identical wages. On the other hand, an account executive might feel that experience on the production side would be so valuable an addition to his resume that he would be willing to take a pay cut in the short run in order to enhance his marketability in the long run. Production work might be more fun than account management, justifying a lower wage, or it might be more arduous or dangerous, justifying a higher wage. Indeed, these factors would vary, not only from one employer to the next, but also within one firm, depending upon the tastes, aspirations, and prospects of each particular employee.

1s See Shultz v. American Can Co.-Dixie Prods., 424 F.2d 356, 360-61 (8th Cir. 1970); Shultz v. Wheaton Glass Co., 421 F.2d 259, 263-64 (3d Cir.), cert. denied, 398 U.S. 905 (1970); cf. 29 C.F.R. $\$ 800.122$ (a) (1983) (in order to determine whether "job differences are so substantial as to make jobs unequal," one must examine whether, and to what extent, "significance has been given to such differences in setting the wage levels for such jobs"). 
cision to compensate differently two employees performing jobs that are claimed to be substantially similar, a court must reckon with the magnitude of the pay differential. The Fifth Circuit recognized this point in Hodgson v. Brookhaven General Hospital, where it announced that for two jobs to be considered "unequal" (because they entail unequal effort), the additional tasks of the more highly compensated position must, inter alia, be "of an economic value commensurate with the pay differential."19

But it is extraordinarily difficult to implement a test that requires the assignment of an "economic value," while prohibiting reference to market valuation. How could one possibly know how "valuable" a certain increment of work is to an employer without "peeking," that is, taking account of the price actually paid for the extra duties in real-world market transactions? The answer must lie in some sort of procedure by which jobs with different characteristics can be cardinally arranged, so that it is possible to determine their value to the employer relative to one another. But relative value can only be measured according to some standard that specifies what job characteristics will be compared and the relative weights to be assigned to those characteristics. In other words, the only way for a judge to implement this part of the Brookhaven test coherently is to refer to the sort of job-evaluation scheme contemplated by the theory of comparable worth..$^{20}$ But there is no such job-evaluation system that would not be subject to endless criticism and disagreement; nor, we suspect, is there ever likely to be: the assignment of relative weights to various job characteristics boils down, in the end, to a subjective judgment, about which people are bound to disagree.

\section{B. Job Segregation}

\section{Hypothetical 4}

$M$ and $F$, hearing of the boss's desire to establish the new position of account/production executive, both approach the boss and express interest. Upon reflection, the boss assigns the production work (and the $\$ 10,000$ raise that goes with it) to $M$. The boss does not have any particular reason for preferring $M$, but rather assigned the work arbitrarily following a mental "coin-flip." 


\section{Hypothetical 5}

Same as Hypothetical 4, except that the boss selects $M$ because she feels that production work is "no job for a lady."

In Hypotheticals 4 and 5, the nature of the combined account/ production job is identical to that depicted in Hypothetical 3. What has been added is an action by the employer that determines which of the two employees, $M$ or $F$, is assigned to the new job. There is no good reason why the means by which employees are assigned to one or another job ought to determine whether the work is "equal" within the meaning of the statute ${ }^{21}$ If we conclude that the employer in Hypothetical 3 is violating the Equal Pay Act by paying unequal wages for equal work, then the same conclusion must follow in Hypotheticals 4 and 5 since the nature of the jobs is the same in all three hypotheticals. In fact, Hypothetical 3 differs from Hypotheticals 4 and 5 only in that the employer in the latter cases based her decisions on arbitrary and gender-based criteria respectively, and these facts would only strengthen the case against her. On the other hand, a decision that the employer in Hypothetical 3 did not violate the Equal Pay Act because the work was not "equal" would imply that Hypotheticals 4 and 5 could not involve violations of the Act because "equal work" is a threshold requirement of the statute.

In a world whose only fair-employment statute was the Equal Pay Act, it would not be surprising if courts were anxious to characterize the jobs in Hypothetical 3 as equal. Without a prohibition on sex discrimination in areas other than compensation, a finding that the two jobs in Hypothetical 3 involved "unequal work" would, following the argument just outlined, mean that the clearly sex-discriminatory conduct in Hypothetical 5, as well as the possibly discriminatory conduct in Hypothetical 4, would escape legal

21 Professor Becker disagrees. See Becker, Comparable Worth in Antidiscrimination Legislation: A Reply to Freed and Polsby, 51 U. CHI. L. REv. 1112, 1117-18 (1984). While it is true, as we have been at pains to indicate, that application of the Equal Pay Act to nonidentical jobs requires consideration of whether the asserted job differences are pretexts for the pay difference, the relevance of job segregation to this inquiry is far from clear. A law firm that refused to hire either female lawyers or male secretaries would undoubtedly be guilty of sex discrimination, but it would hardly be guilty of wage discrimination simply because the secretaries were paid less than the lawyers. If the equal-pay limitation is to have any force, the equality of jobs must be determined by focusing on the nature of the jobs, not on whether the employer has a defective character. If two jobs are so different that one can imagine employers paying different wages for them, then they are not "equal" work. We do not dispute the fact that this methodology entails, in practice, a job-comparability analysis; indeed that is one of the main points of this article. 
sanction. ${ }^{22}$ But if judges found the work to be "equal," they would in effect be quarreling with the legislative decision to prohibit employers only from paying unequal wages for equal work and, in effect, to permit broader classes of sex-discriminatory employment practices.

We do not, however, live in a world where the only fair-employment statute is the Equal Pay Act. Title VII of the Civil Rights Act of $1964^{23}$ prohibits sex discrimination in hiring, promotion, and assignments, as well as in compensation. ${ }^{24}$ Thus, a judge faced with the situation posed by Hypothetical 3 need not worry that deciding that the work is unequal will preclude the imposition of legal liability on the employer in Hypotheticals 4 and $5 .^{28}$ Nevertheless, it appears that courts have to some extent allowed the manner in which jobs were assigned to influence their decision on whether the work was "equal." Most of the leading Equal Pay Act cases on the issue of "equal work" are cases in which the jobs being compared were overtly segregated by sex, with men assigned to the higher-paying jobs. ${ }^{26}$ None of these cases involved Title VII challenges to the segregation itself. It is hard to avoid the suspicion that the segregation of the workforce affected the courts' rejection of the employers' assertions that the jobs were indeed unequal. To make matters worse, pronouncements concerning the characteris-

${ }^{22}$ We assume that the equal protection clause of the fourteenth amendment, U.S. Const. amend. XIV, § 2, is not applicable.

2342 U.S.C. $\S \S 2000$ e to $2000 \mathrm{e}-17$ (1982).

24 Civil Rights Act of 1964, tit. VII, § 703(a)(1), 42 U.S.C. § 2000e-2(a) (1982).

2s In a particular case, of course, a court might be faced with a situation like that in Hypothetical 4 or 5 in which a failure to find an Equal Pay Act violation will allow the particular defendant to escape liability despite the existence of Title VII. For example, if no timely Title VII claim has been filed, the Equal Pay Act claim may provide the only opportunity to subject this particular employer to civil liability. In addition, Professor Becker points out that job segregation may be lawful under Title VII because of that statute's "bona fide occupational qualification" defense, Civil Rights Act of 1964, tit. VII, § 703(e)(1), 42 U.S.C. § 2000e-2(e)(1) (1982). See Becker, supra note 21, at 1117. Professor Becker then argues that the Equal Pay Act is an appropriate vehicle to "remedy" this sort of segregation. Id. at 1118. But a court that was willing to impose Equal Pay Act liability because of the unavailability of relief under Title VII in the particular case would essentially be amending Title VII. Supposed deficiencies in the Title VII remedial scheme, however, should have no bearing on the issue of equal work under the Equal Pay Act.

28 See, e.g., Corning Glass Works v. Brennan, 417 U.S. 188, 191-92 (1974) (only male inspectors assigned to the higher-paying night shift); Shultz v. American Can Co.-Dixie Prods., 424 F.2d 356, 358 (8th Cir. 1970) (only male machine operators assigned to the higher-paying night shift); Shultz v. Wheaton Glass Co., 421 F.2d 259, 264 (3d Cir.) (male selector-packers paid more than female selector-packers because of additional duties assigned only to the males), cert. denied, 398 U.S. 905 (1970); Wetzel v. Liberty Mut. Ins. Co., 449 F. Supp. 397, 399 (W.D. Pa. 1978) (lower-paying claims-representative positions filled exclusively by females). 
tics of equal work have been relied upon by courts in situations where illegal job segregation seems not to have been present. ${ }^{27}$

\section{Equal/Unequal Employees}

When employer and employee agree on a given salary, economic theory asserts axiomatically that the agreed-upon salary is equal to or lower than the employee's anticipated marginal value to the employer. ${ }^{28}$ But when an enterprise employs several persons, the employer can know with certainty only whether the enterprise as a whole is a success or a failure. It is often difficult to apportion credit (or blame) for results among the various factors of production (e.g., employees, raw materials, and production equipment) or among various individual employees. Like many questions of multiple causation, deciding what value to assign to some employee's marginal product is a matter of judgment rather than a scientific endeavor. Yet, as it turns out, the Equal Pay Act requires employers to engage in something like a "scientific" ascertainment of the proper wage to pay each employee.

\section{A. The Two-Employee Situation}

In order to justify or explain differential compensation of two employees who are doing the same or similar jobs, the employer will have to point to objective differences between the two employees in their credentials, skills, or performance, and will, moreover, have to persuade a court that these differences affect the employees' productivity.

\section{Hypothetical 6}

Same as Hypothetical 2 (unequal initial offers to $M$ and $F$ despite equal objective factors), except that the boss explains her higher offer to $M$ by describing her "gut feeling" that $M$ is a "real go-getter," while $F$, although well qualified in many

${ }^{27}$ See Hodgson v. Brookhaven Gen. Hosp., 436 F.2d 719, 725 (5th Cir. 1970) (female nurse's aides paid less than male orderlies); Grove v. Frostburg Nat'l Bank, 549 F. Supp. 922, 933 (D. Md. 1982) (female loan tellers alleged sex discrimination with regard to pay and other benefits); Pedreyra v. Cornell Prescription Pharmacies, Inc., 465 F. Supp. 936, 945 (D. Colo. 1979) (female pharmacist paid less than male pharmacists); United States v. City of Milwaukee, 441 F. Supp. 1371, 1375 (E.D. Wis. 1977) (female police matrons paid less than male jailers); Ridgway v. United Hospital-Miller Div., 13 Empl. Prac. Dec. (CCH) I 11,313, at 6042 (D. Minn. 1976) (female practical nurse and female opthamology technician paid less than male urology assistant), aff'd in part, rev'd in part on other grounds, $563 \mathrm{~F} .2 \mathrm{~d} 923$ (8th Cir. 1977).

se See, e.g., Cox, supra note 4, at 86-87. 
respects, appears to lack initiative.

The employer here is claiming that the difference in salary was not a product of sex discrimination, but rather was a product of the employer's good-faith attempt to evaluate the respective merits of the two employees. Within the structure of the Equal Pay Act, the employer is attempting to assert an affirmative defense-either the "merit system" defense ${ }^{29}$ or the "any other factor other than sex" defense. ${ }^{30}$ The former claim would receive short shrift from the court because a "merit system" requires certain formal characteristics denoting a "system": for example, notice to the affected parties, consistency, and objectivity. ${ }^{31}$ Some courts might entertain the latter defense, but in general there is a fairly heavy presumption against acceptance of the "other factor" defense. ${ }^{32}$ The courts' rationale is that subjective evaluations, such as those in Hypothetical 6, leave open too great a possibility for illicit discrimination. ${ }^{33}$

\section{Hypothetical 7}

Same as Hypothetical 6; except that, instead of referring to her "gut feeling," the boss asserts that she offered more money to $M$ because $M$ has an M.B.A. while $F$ only has a bachelor's degree; $M$ has worked for two years as a marketing manager for a large department store, while $F$ is fresh out of college; and $M$ 's bachelor's degree and M.B.A. are from Stanford, while $F$ 's bachelor's degree is from Obscure College. The boss introduces into evidence a salary-determination formula in which each year of education and each year of post-college work experience are worth a particular dollar amount and an

2929 U.S.C. $\S 206(d)(1)(i i)$ (1982).

so Id. § 206(d)(1)(iv).

31 See, e.g., EEOC v. Whitin Mach. Works, Inc., 635 F.2d 1095, 1097-98 \& n.6 (4th Cir. 1980); Brennan v. Victoria Bank \& Trust Co., 493 F.2d 896, 901 (5th Cir. 1974); Hodgson v. Brookhaven Gen. Hosp., 436 F.2d 719, 726 (5th Cir. 1970); cf. 29 C.F.R. § 800.144 (1983) (an informal or unwritten merit system may qualify under the statutory language if the standards or criteria of the system are applied pursuant to an established plan, the essential terms of which have been communicated to employees).

${ }^{32}$ See, e.g., Brennan v. Owensboro-Davies County Hosp., 523 F.2d 1013, 1031 (6th Cir. 1975) ("[T]he burden of proving that a factor other than sex is the basis for a wage differential is a heavy one."), cert. denied, 425 U.S. 973 (1976); 29 C.F.R. § 800.142 (1983) (the requirements for proving that wage differentials are based on "any other factor other than sex" are not met "unless the factor of sex provides no part of the basis for the wage differential").

3s See, e.g., Brennan v. Victoria Bank \& Trust Co., 493 F.2d 896, 902 (5th Cir. 1974) ("[T]he subjective evaluations of the employer cannot stand alone as a basis for salary discrimination based on sex [because if] this were allowed, 'the exception will swallow the rule.' ") (quoting Shultz v. First Victoria Nat'l Bank, 420 F.2d 648, 657 (5th Cir. 1969)). 
additional salary increment is provided to applicants whose degrees are from the boss's short list of prestigious universities.

There is language in numerous cases suggesting that such a systematic and objective method for computing salary places the boss on firmer ground in attempting to establish an affirmative defense to an Equal Pay Act claim. ${ }^{34}$ Since the Equal Pay Act is concerned with the eradication of illicitly motivated pay differentials, it is not surprising that courts are more willing to accept concrete explanations for such differentials than they are descriptions of "gut feelings."

But while the boss will certainly have a stronger case, she will by no means be home free. Indeed, so many lines of attack have surfaced in decided cases that the advantage in providing objective explanations actually appears quite small. Numerous courts appear to take the position that differences in education, experience, and other "human capital" qualifications of particular employees are immaterial if the employer is hiring for jobs that are "substantially equal."ss Other courts, apparently adopting an approach first announced by the Supreme Court in the Title VII case of Griggs $v$. Duke Power Co., ${ }^{36}$ require the employer to demonstrate that the criteria selected are related to job performance. ${ }^{37}$ And some courts,

s4 See, e.g., Marshall v. Security Bank \& Trust Co., 572 F.2d 276, 279 (10th Cir. 1978); Brennan v. Victoria Bank \& Trust Co., 493 F.2d 896, 901 (5th Cir. 1974).

ss See, e.g., Peltier v. City of Fargo, 533 F.2d 374, 377-79 (8th Cir. 1976); United States v. City of Milwaukee, 441 F. Supp. 1371, 1374-75 (E.D. Wis. 1977); Di Salvo v. Chamber of Commerce, 416 F. Supp. 844, 853 (W.D. Mo. 1976), aff'd in part, modified in part on other grounds, 568 F.2d 593 (8th Cir. 1978); Wirtz v. Basic Inc., 256 F. Supp. 786, 790-91 (D. Nev. 1966). In effect, this principle follows from the proposition that there is no market defense. Differences in such human-capital factors, if the employer does not claim that they result in differences in productivity in the particular job, are merely factors that go to the market wage of employees - that is, they affect the employee's next-best alternative.

36 401 U.S. 424, 431-32 (1971).

37 See Kouba v. Allstate Ins. Co., 691 F.2d 873, 876-78 (9th Cir. 1982); EEOC v. First Citizens Bank, 31 Empl. Prac. Dec. (CCH) I 33,508 (D. Mont. 1983); see also EEOC Proposed Equal Pay Act Interpretations, 46 Fed. Reg. 43,848, 43,852 (1981) (to be codified at 29 C.F.R. $\$ 1620.12 b(4)$ ) (a facially neutral practice "is discriminatory if it has an adverse impact on members of one sex in providing them a lower rate of pay and if it cannot be shown to be related to job performance"); C. Sullivan, M. Zimmer \& R. Richards, Fedraral StatuTORY LAW OF EMPLOYMENT Discrimination $\S 10.8$, at 622-25, § 10.9, at $629-30$ (1980) (when there is a disproportionate adverse impact on a gender basis, the employer must show that the practice is justified by business necessity). Adoption of Title VII's disparate-impact theory in this context should be controversial. We agree with Professor Cox that the correct way to interpret the Equal Pay Act is as embodying only the disparate-treatment concept of discrimination. See Cox, supra note 4, at 66-67; Freed \& Polsby, Privacy, Efficiency, and the Equality of Men and Women: A Revisionist View of Sex Discrimination in Employ- 
while accepting the relevance of the employer's proffered criteria, will nonetheless reject the defense because they conclude that the wage differential is disproportionate to any expected benefit to the employer that is attributable to the difference between the two employees' qualifications. ${ }^{38}$

The boss would face similar difficulties if she hired $M$ and $F$ at equal initial salaries for the "same job," but gave $M$ larger raises than $F$ over the course of the next few years and attempted to justify her behavior on the basis of a difference between the on-thejob performances of $M$ and $F$. For example, if the boss claims that $M$ writes much better copy than $F$, she may well be faced with the response that an employer's evaluation of such an inherently subjective factor may in fact reflect the sort of invidious discrimination that the Act is intended to eradicate. ${ }^{39}$

Even if the employer points to something more concrete as evidence of productivity, there is still a good deal of room for objection by a plaintiff. For example, the boss might note that twice in the course of the last three years, $M$, on his own initiative, undertook to design an entirely new and improved campaign for a client who was apparently satisfied with the campaign already in place, and as a result of this initiative the agency's income increased substantially. One might object, however, that such an opportunity to show initiative is highly contextual-for example, it may be nothing but happenstance that $M$ was responsible for two accounts that were in need of overhaul-and a salary increase, as distinct from a bonus, is therefore unwarranted..$^{40}$ Or, if the boss had a system of pegging raises to some dollar measure of productivity (such as rev-

ment, 1981 Am. B. Found. Research J. 585, 630 n.156. For an especially useful general discussion of both the disparate-treatment and disparate-impact theories of discrimination, and an argument that the latter theory is incoherent, see Cox, Substance and Process in Employment Discrimination Law: One View of the Swamp, 18 VAL. U.L. Rev. 21 (1983).

ss See, e.g., Shultz v. Wheaton Glass Co., 421 F.2d 259, 266-67 (3d Cir.), cert. denied, 398 U.S. 905 (1970); Futran v. Ring Radio Co., 501 F. Supp. 734, 739 (N.D. Ga. 1980); Di Salvo v. Chamber of Commerce, 416 F. Supp. 844, 852-53 (W.D. Mo. 1976), aff'd in part, modified in part on other grounds, 568 F.2d 593 (8th Cir. 1978).

39 See Marshall v. Security Bank \& Trust Co., 572 F.2d 276, 279 (10th Cir. 1978); Melani v. Board of Higher Educ., 561 F. Supp. 769, 778 (S.D.N.Y. 1983); EEOC v. First Citizens Bank, 31 Empl. Prac. Dec. (CCH) I 33,508 (D. Mont. 1983); Grove v. Frostburg Nat'l Bank, 549 F. Supp. 922, 934 (D. Md. 1982); Pedreyra v. Cornell Prescription Pharmacies, Inc., 465 F. Supp. 936, 947 (D. Colo. 1979); cf. Brennan v. Victoria Bank \& Trust Co., 493 F.2d 896, 901-02 (5th Cir. 1974) (employer's subjective evaluations based on college and work experience, an aptitude test, and an assessment of the applicants' personality and apparent ability during an interview cannot justify wage differentials since they may simply reflect discrimination based on sex).

to See Grove v. Frostburg Nat'l Bank, 549 F. Supp. 922, 933-34 (D. Md. 1982). 
enues generated by accounts within the responsibility of the respective account executives), such differences in productivity might be a product of differential opportunities that were afforded to $M$ and $F .^{41}$

Not every court faced with the sorts of explanations we have described would reject them as insufficient. But where a court is inclined to reject such explanations, the employer may be faced with a sort of "Catch 22" in attempting to defend the action: an explanation, submitted by the employer as exculpatory, may be seen by the court as possible further evidence of the depth and pervasiveness of discrimination in the employer's overall operation. ${ }^{42}$ Whether the court accepts the employer's explanation or regards it as tainted by the possibility of discrimination will simply depend on how strongly the court believes that, if the employer were truly acting in a nondiscriminatory manner, there would be no wage disparities at all between men and women.

\section{B. The Multiple-Employee Situation}

For the most part, the cases coming to court today do not involve situations in which the employer has only two employees performing the job in question, or in which jobs are formally segregated by sex. More typically, the cases present a scatter of employees and wages. For example, an employer might have three employees, $M-1, F-1$, and $M-2$, performing "equal" work. If $M-1$ is paid $30, F-1$ is paid 25 , and $M-2$ is paid 20 , does $F-1$ have a valid Equal Pay Act claim? The court must decide whether $F-1$ 's salary is to be compared with $M-1$ 's or with $M-2$ 's, and whether differences between the employees justify or explain the pay differentials. If an employer's work force displays a hodge-podge of wages in which both men and women are receiving "unequal pay for equal work," the conventional view is that any given woman can establish a prima facie case of discrimination by pointing to any man who is being paid a higher salary for "equal work." It is an open question whether an employer could successfully defend against such a claim by showing that there were also male employ1977).

4l See id.; United States v. City of Milwaukee, 441 F. Supp. 1371, 1374, 1376 (E.D. Wis.

42 See infra notes 71-80 and accompanying text (discussing Melani v. Board of Higher Educ., 561 F. Supp. 769 (S.D.N.Y. 1983)).

13 See, e.g., Board of Regents v. Dawes, 522 F.2d 380, 383 (8th Cir. 1975), cert. denied, 424 U.S. 914 (1976); Hodgson v. American Bank of Commerce, 447 F.2d 416, 421 (5th Cir. 1971); C. SullivaN, M. ZimMer \& R. RIChards, supra note 37, \$ 10.6, at 598. 
ees performing equal work who were likewise paid less than the male upon whose salary the female plaintiff is basing her claim, but it has been suggested that the female plaintiff could prevail, even if the other male employees' lesser salaries were unjustified or unexplained. ${ }^{44}$

Instead of looking at individual employees' salaries, one might also seek to establish an inference of discrimination from patterns of differential wages that can be discerned through statistical analysis. That is, if an employer has enough employees to make meaningful statistical analysis possible, the average salary of all the female employees in a particular job can be compared with the average salary of all the males in the same job. Various statistical methods (principally multiple regression analysis) allow a determination of how much of the difference in average salary between men and women is explainable by various differences in the qualifications or productivity of particular employees. For example, plaintiffs might introduce a multiple regression analysis that compares the salaries of all employees after controlling for such factors as age, education, work experience, and seniority. If there is a difference in the average salary of men and women that is left unex-

4 Sullivan, Zimmer, and Richards offer the example of an employer with four employees doing equal work where $M-1$ and $F-1$ are paid 10 , and $M-2$ and $F-2$ are paid 9. C. SulurVAN, M. ZiMMer \& R. Richards, supra note $37, \S 10.6$, at 599-600. According to these authors, $F-2$ can establish a prima facie case of sex discrimination by pointing to $M-1$ 's higher salary, notwithstanding the presence of a mirror-image disparity between $F-1$ and $M-2$. The authors defend placing the burden on the employer by noting that the employer is in the best position to explain its employees' salary array. The existence of the $F-1 / M-2$ disparity itself is "probative of a non-sex basis" for the salary differences, although it might well be necessary for the employer to proffer other evidence of reasons underlying the salary decisions. Id. at 600 .

If an employer does have to present additional evidence to justify or explain such salary disparities, it will be subject to all the perils we have described: an explanation focusing merely on the acceptance by the various employees of these wages would be rejected out of hand, and other sorts of explanations would be subject to rejection on the grounds that they were not systematic enough, that they reflected subjective, "tainted" criteria, and so forth. See supra note 42 and accompanying text. Indeed, one who presumes that employers often engage in some form of sex discrimination could easily suspect that, in the absence of discrimination, $F-1$ would actually be making more than $M-1$, and $F-2$ would be making more than $M-2$. If, for example, $F-1$ "should" be paid $11, M-110, F-210$, and $M-2$ 9, then $F-2$ is clearly a victim of an Equal Pay Act violation vis-à-vis the salary paid to $M-1$, and the fact that $F-1$ is paid the same as $M-1$, far from being exculpatory, is incriminating. Numerous Equal Pay Act cases involve such judicial attempts to decide whether particular employees can appropriately be compared under the statute. See, e.g., EEOC v. First Citizens Bank, 31 Empl. Prac. Dec. (CCH) II 33,508 (D. Mont. 1983); Grove v. Frostburg Nat'l Bank, 549 F. Supp. 922 (D. Md. 1982); Di Salvo v. Chamber of Commerce, 416 F. Supp. 844 (W.D. Mo. 1976), aff'd in part, modified in part on other grounds, 568 F.2d 593 (8th Cir. 1978); Wirtz v. Basic Inc., 256 F. Supp. 786 (D. Nev. 1966). 
plained by these variables, plaintiffs have a prima facie showing of sex discrimination.

The recognition of such a statistical showing as a prima facie case is based upon the assumption that, in the absence of discrimination, there will be no statistically significant difference between the average salaries of equally qualified men and women. This assumption is not uncontroversial, but controversial or not, it is important to observe how it relates to a number of the points we have already made. Suppose the statistical analysis indicates that the difference in average salary between men and women is explained completely by differences in such factors as education and experience. But suppose further that the employer does not consciously set salaries on the basis of such factors, but rather proceeds on the basis of unstructured, unsystematic reactions to various employees' qualifications and productivity. An employer that offered such subjective or unsystematic explanations for the disparity between any two particular employees would almost certainly lose an Equal Pay Act case. ${ }^{45}$ When the employer's overall decisions are subjected to statistical analysis, however, the same assumptions that lead to an inference of discrimination where salary differences are left unexplained would be deemed to show that the employer's selfsame subjective decisionmaking process is untainted by sex discrimination.

Of course, in the real world, statistical disparities between the salaries of men and women can rarely be completely explained by factors measuring productivity or qualifications; the burden is thus easily shifted to the employer to rebut the prima facie case. In such cases, the employer is likely to object to the model underlying the plaintiff's regression analysis on the ground that crucial variables have been omitted, and that such variables would explain the otherwise unexplained difference in salary. The employer, however, is likely to encounter precisely the same sort of "Catch 22 " that we observed in the two-employee hypotheticals: any factor offered as an explanation or justification for the salary differential may itself be seen as tainted with discrimination. ${ }^{16}$ Further, statistical wagediscrimination cases may press beyond the statutory domain of "equal work" into the uncharted seas of "comparable worth."

48 See supra notes $29-33$ and accompanying text.

46 See supra text accompanying note 42; see also infra notes 71-80 and accompanying tert (discussing "Catch 22" in Melani v. Board of Higher Educ., 561 F. Supp. 769 (S.D.N.Y. 1983)). 


\section{Combinations and Permutations}

To this point, our analysis of the Equal Pay Act has been largely abstracted from the real world. In this part we focus on several cases to see how the observations we have made work themselves out in practice. These cases, which are of relatively recent vintage, cumulate and employ the doctrines noted in previous sections.

\section{A. United States $v$. City of Milwaukee}

United States $v$. City of Milwaukee ${ }^{47}$ involved questions about the equality of both jobs and employees in a setting where jobs were lawfully segregated. Male prisoners at the Milwaukee jail were under the supervision of "jailers," all of whom were male, while female prisoners were supervised by "matrons," all of whom were female. Both matrons and jailers received two weeks of inservice and first-aid training. But jailers were also full-fledged police officers, trained and disciplined as such; and they were issued weapons and trained in their use, although they were not allowed to carry the weapons while on duty at the jail. In terms of their day-to-day duties, the jailers and matrons performed substantially identical functions at the jail. Each matron, however, was responsible for an average of five to seven prisoners, while each jailer was responsible for an average of fifteen to twenty prisoners. Moreover, the jailers, who were on twenty-four-hour active duty as police officers, were obliged by official regulations to carry their weapons whenever they were not actually in the jail and to act upon their statutory power of arrest for any crime committed in their presence. Matrons earned between $\$ 11,800$ and $\$ 13,500$ per year; jailers, who were compensated at the same scale as other police officers, earned between $\$ 14,000$ and $\$ 16,400$ per year.

The court concluded that, as a matter of law, matrons and jailers performed substantially equal work ${ }^{48}$. because both were required to do basically the same tasks while on duty at the jail.99

47441 F. Supp. 1371 (E.D. Wis. 1977).

6s Plaintiffs did not actually raise an Equal Pay Act claim. See id. at 1372-73. They did, however, claim violations of Title VII, and the court stated that "[ $t$ ] VII regarding discrimination in compensation based on sex are to be construed in pari materia with the Equal Pay Act . . . ." Id. at 1375 (citations omitted). Consequently, the court's analysis of the equal-work issue is identical to what it would be under an Equal Pay Act claim.

49 These duties included conducting body and custodial searches of prisoners, preparing inventories of prisoners' property, feeding prisoners, and managing phone calls. Id. at 1373. 
The court considered it irrelevant that jailers received more training than did matrons and were available for assignment to regular police work because neither factor was related to performance of the job in the jail proper. ${ }^{50}$ Nor did the court consider it important that the jailers were obliged to supervise more inmates at any given time since there was no showing that matrons would have been unwilling to handle as many prisoners as the jailers. ${ }^{51}$

Two aspects of this decision are particularly noteworthy. First, the court concluded that the jailers' twenty-four-hour active duty status as police officers was "unrelated to their work as jailers" and, therefore, did not justify paying jailers more than matrons. ${ }^{62}$ Does this mean that the city may not compensate jailers at all for the extra obligations that they have as policemen? Perhaps when employees are held in reserve by an employer against the possibility of an emergency or unforeseen blips in the work load, they cannot be paid at all unless and until the anticipated contingency occurs because only then is their reserve status valuable to an employer. ${ }^{53}$ Although the Milwaukee jail case is a rather poignant example, numerous cases have similarly rejected claims of flexibility as a reason for paying a higher wage absent a showing that the flexibility is taken advantage of with some frequency. ${ }^{54}$

The second noteworthy aspect of the case is the court's treatment of the large difference between the number of inmates for which matrons and jailers were, on average, responsible. According to the court:

[T] here has been no showing made that the matrons would be unwilling or unable to process and to care for a greater num-

so Id. at 1374 .

s1 Id.

Id.

83 Another possibility is that the city could compensate the jailers for their extra responsibilities, but must do so with two different paychecks, one from the jail equal to the salary of the matrons, and a second from the police department for the additional duties. This approach might be practicable, but it hardly embodies a sensible legal distinction, for it depends on the artificial conclusion that the city violated the civil-rights laws of the United States by putting the wrong job title on the paycheck.

o See, e.g., Peltier v. City of Fargo, 533 F.2d 374, 377-79 (8th Cir. 1976) ("[T]o justify unequal wages on the basis of alleged flexibility requires inquiry into the frequency and manner in which that additional flexibility is utilized."); Shultz v. Wheaton Glass Co., 421 F.2d 259, 263-64 (3d Cir.) ("A 10\% wage differential is not automatically justified by showing that some advantage exists to the employer because of a flexibility whose extent and economic value is neither measured nor determined . . .."), cert. denied, 398 U.S. 905 (1970); cf. supra text accompanying note 18 (discussing argument that employer must pay piecework rate instead of standard wage where amount of additional work performed varies from employee to employee). 
ber of prisoners if required to do so by the defendant City of Milwaukee. Further, the differential, if any, in the quantity of work performed by the jailers and matrons results from the hiring policy of the defendant City of Milwaukee and the number of positions for jailers and matrons which it has chosen to create and not from a differential in training or ability between matrons and jailers. Under those circumstances, the possible difference in the quantity of work performed does not affect the determination of whether matrons and jailers perform equal work. .s $^{\text {s. }}$

In other words, so long as the city could have hired either more jailers or fewer matrons, the fact that each matron actually hired was responsible for fewer inmates than each jailer actually hired was of no importance. This means that an employer cannot use the fact that one job is more demanding than another as a reason for paying incumbents in that job a premium if it is possible-and it will always be possible-to rearrange the work so as to eliminate such differences. For example, if an employer pays $A$ more than $B$ because $A$ 's job involves lifting big trash cans while $B$ need only lift little trash cans, one might ask why the employer does not simply replace $A$ 's big trash cans with lots of little trash cans, thereby eliminating the difference between $A$ 's job and $B$ 's job. Alternatively, the jobs held by $A$ and $B$ could be combined and shared, so that each is doing a mixture of light and heavy work, and the difference between their jobs would be eliminated.

The notion that employers may violate the Equal Pay Act by deploying their labor force in one way rather than another is not a sport in equal-pay cases. ${ }^{58}$ Judicial uneasiness with suspected underlying patterns of illicit job segregation has influenced courts' decisions on whether "equal work" was involved. These decisions have in turn mischievously influenced the outcomes of equal pay cases that did not involve illicit job segregation and where the only similarity was the issue of "equal work."

It is surely tempting to treat City of Milwaukee as a wrongly decided aberration. ${ }^{58}$ But while this decision is silly, it is far from clear that it is indeed an aberration. In fact, it is perfectly consistent with the approach of the numerous leading Equal Pay Act

ss 441 F. Supp. at 1374.

se See supra notes 13-19 and accompanying text.

s7 See, e.g., Grove v. Frostburg Nat'l Bank, 549 F. Supp. 922 (D. Md. 1982); Pedreyra v. Cornell Prescription Pharmacies, Inc., 465 F. Supp. 936 (D. Colo. 1979).

See Becker, supra note 21, at 1120-21. 
cases upon which the City of Milwaukee court relied.

\section{B. Winkes v. Brown University}

Winkes $v$. Brown University ${ }^{59}$ is an example of a court rejecting labor-market explanations for pay disparities and expressing skepticism about "non-objective" and "unsystematic" methods of distinguishing between employees who were concededly performing equal work. Plaintiff Rudolph Winkes was a tenured associate professor of art history at Brown University, as was Catherine Zerner. When Zerner was offered tenure, her salary was initially to be commensurate with that of Winkes, who was already tenured. But before that salary went into effect, Zerner received an offer from Northwestern's art history department for the coming academic year at a salary approximately thirty-seven percent higher than Winkes's salary was to be at Brown. Brown matched the Northwestern offer, and Zerner decided to remain. Feeling that the pay disparity between Zerner and Winkes was inequitable, Brown adjusted Winkes's salary upward, somewhat reducing the gap, and awarded him overscale salary increases in subsequent years that further narrowed the disparity between his salary and Zerner's. Winkes alleged that Brown had violated the Equal Pay Act by paying Zerner more than it paid him for equal work and proffered as evidence of Brown's illicit sex-based motivation the fact that the university had subscribed to a consent decree in a sex-discrimination case that obliged it to increase the number of tenured women on the Brown faculty.

The university offered three related justifications for its actions. First, it sought to rely upon the "merit system" defense to the Equal Pay Act, ${ }^{80}$ arguing that Zerner's scholarship was superior to that of Winkes. ${ }^{81}$ The court rejected this defense because there was no showing that the university had put the faculty on notice of any objective, systematic review procedure involving predetermined criteria. ${ }^{62}$ Second, the university argued that outside offers are a recognition of scholarly merit and amount to a form of peer review that may be relied upon by an employer under the merit-

so 32 Fair Empl. Prac. Cas. (BNA) 1041 (D.R.I. 1983). As this article went to press, the First Circuit Court of Appeals reversed the district court's judgment in Winkes. Winkes v. Brown Univ., No. 83-1649 (1st Cir. Oct. 26, 1984). The First Circuit's decision is discussed infra note 70.

029 U.S.C. $\$ 206(d)(1)(i i)$ (1982).

or Winkes, 32 Fair Empl. Prac. Cas. at 1046.

2 Id. 
system exception. ${ }^{63}$ The court rejected this argument as well: in order for such a policy of meeting outside offers to amount to a merit system, it too must conform to the above-mentioned criteria. ${ }^{\text {*4 }}$ Because responses to outside offers varied substantially within the university, and because there appeared to be no systematic criteria for deciding when offers would or would not be met, the justification failed. ${ }^{65}$ Brown's final argument was that the difference in salary was a differential based on market forces, thereby falling within the Act's "any other factor other than sex" exception. ${ }^{8 B}$ The court, assuming arguendo that a market-force defense could be made out under the Equal Pay Act, rejected the defense on the ground that, because Brown did not engage in a systematic inquiry into academic labor market conditions, it did not prove a link between the wage differential and market conditions. ${ }^{67}$

The Winkes court found that, even if market forces played some role in the university's decision to meet the outside offer, that decision was still tainted by the influence of Zerner's sex because Brown would not have met the Northwestern offer if not for the consent decree requiring Brown to increase the number of tenured women faculty. ${ }^{68}$ While this factor may explain the result of the case, it does not diminish the import of the Winkes court's approach to the university's proffered defenses. The court treated Brown's arguments as insufficient as a matter of law, quite apart from its assessment of the university's motive. Accordingly, Winkes suggests that it would be difficult for an employer to justify paying any employee ${ }^{69}$ more than another in the same job,

os Id.

of Id. at 1046-47.

os Id. at 1047.

o6 Id.; see 29 U.S.C. § 206(d)(1)(ii) (1982).

${ }^{67}$ Defendants have not proved that the salary paid to Professor Zerner, and the resulting wage differential between Professor Zerner and Winkes, resulted from the force of the academic market place. No evidence was presented which would indicate what the job market was like for Art History Professors in 1978. No availability of positions, estimated applicant pools or salary ranges of various institutions were discussed. Defendants based their presumptions concerning the Art History market solely on the single salary quotation from Northwestern University. Defendant Glicksman stated that he did not even know if the employment offer was gratuitous or solicited by Professor Zerner. . . . Defendants seek to justify Professor Zerner's salary on assumptions as to her professional worth and her apparent value to a single outside institution. Such tenuous evidence cannot sustain a market force defense.

Winkes, 32 Fair Empl. Prac. Cas. at 1048.

es Professor Becker makes this point. See Becker, supra note 21, at 1122.

6o Winkes involved discrimination against a male, but the court would surely have reached the same result had the seres been reversed. Indeed, given the conventional view that the Equal Pay Act is principally for the benefit of female employees, a Winkes situa- 
even where the motive is only to retain the former's services in the face of an attractive outside offer.

How is an employer supposed to respond to such a legal rule? On the one hand, an employer in this situation can retain the employee only if it meets the outside offer and also raises to the same level the salaries of other employees performing the same work. Consequently, this rule significantly raises the costs of retaining recipients of outside offers, thereby making it less likely that employers will attempt to retain such employees. On the other hand, employers will also be less likely to make outside offers in the first place, for fear that the premium that must be paid to induce a defection from another employer will have to be granted to all incumbents as well. In brief, employees' mobility will be decreased. While the effect of this decreased mobility may not manifest itself as a lowering of average wages, there is sure to be a "leveling effect" on salaries: employees who, in the absence of the rule, would be able to move relatively easily into areas where they could otherwise-for whatever reason-command premiums will be unable to do so.

While Winkes may indeed have been rightly decided under the Equal Pay Act, and while its approach to the affirmative defenses raised by the university is fully consistent with the corpus of Equal Pay Act decisions, ${ }^{70}$ we leave it to the reader to evaluate the

tion in which it was the male who received the increased salary would present, if anything, a stronger case for finding a violation of the Act.

${ }^{70}$ See Becker, supra note 21, at 1122-26. The First Circuit recently reversed the district court's judgment in Winkes, Winkes v. Brown Univ., No. 83-1649 (1st Cir. Oct. 26, 1984), for two related reasons. First, the district court should not have placed conclusive reliance on the consent decree as establishing the university's sex-discriminatory motivation in meeting Professor Zerner's outside offer. Id., slip. op. at 5-11. Second, a policy of meeting outside offers, if it is not linked to the sex of the recipient of the offer, is a "factor other than sex" justifying a wage differential under the Equal Pay Act. Id. at 4-5, 12-14.

The First Circuit's characterization of a policy of meeting outside offers as a "factor other than sex" amounts to acceptance of the "market defense" that has regularly been rejected in Equal Pay Act cases. See supra note 11. There is no formal difference between an unequal wage when prompted by an outside offer and any other unequal wage that reflects or responds to existing market conditions. Cf. supra pp. 1085-86. Indeed, a market that discriminates by undervaluing the labor of women is a fundamental assumption of the statute; that is the problem for which the Equal Pay Act was supposed to be the solution. See supra note 8 and accompanying text. If this rationale for reversing the district court in Winkes is generally accepted, the Equal Pay Act will become a rule of etiquette, rather than a rule with real prohibitory force. And if this holding were repeated in other Equal Pay Act cases, it would confirm the burden of our argument in text that the statute, as intended to be applied to overcome the prejudices of the market, leads unavoidably to impractical and often normatively unappealing decisions.

Of course, the First Circuit's decision in Winkes may ultimately be limited to its affirmative action/consent decree facts, or to situations in which a policy of meeting outside offers 
desirability of such decisions.

\section{Melani v. Board of Higher Education}

The recent decision of the United States District Court for the Southern District of New York in Melani v. Board of Higher Education $^{71}$ illustrates the tendencies of courts considering a claim resting on statistical analyses both to place the employer in a "Catch 22" situation and to slide into comparable-worth type issues. Although the claim in Melani was brought under Title VII, the decision involves many of the same issues that arise under the Equal Pay Act. In Melani, the plaintiffs were female members of the instructional staff ${ }^{2}$ at the City University of New York (CUNY), a university with a number of separate four-year and two-year colleges and a distinguished graduate school. Plaintiffs submitted several multiple regression analyses of the salaries of instructional staff of the university as a whole. After controlling for ninety-eight independent variables, ${ }^{73}$ the study determined that male instructional staff members were on average paid $\$ 1800$ more than female members.

Among the numerous questions raised by the defendant concerning the validity of these results were two objections of special interest concerning the probative value of the plaintiffs' regression analyses. First, the university argued that the studies omitted critical independent variables measuring the faculty members' academic productivity both while at CUNY and prior to their CUNY employment. ${ }^{74}$ Second, it argued that the plaintiffs should also

is applied to enhance a woman's salary, but not a man's. The latter limitation would be justified by the observation that the Equal Pay Act conception of a discriminatory market is a conception of a market that discriminates against women, not in favor of women. It is only when women are disfavored by the market, therefore, that the statute's policies would be implicated. If Winkes turns out to be a case of such limited significance, then the problems we have identified in this article will remain.

${ }^{71} 561$ F. Supp. 769 (S.D.N.Y. 1983).

72 "Instructional staff" included "both the teaching positions of professor, associate professor, assistant professor, lecturer and instructor, as well as administrative and service positions such as registrar, college laboratory technician, and the higher education officer ...." Id. at 772 .

78 These variables included:

various measurements of age, years of CUNY service, academic degrees, quality of academic degree, certificates and credentials (such as R.N., C.P.A. or Public Engineer), time elapsed since the completion of each degree, and time elapsed between the completion of successive degrees. An independent variable for sex was included in each of the analyses.

Id. at 774.

${ }^{74} I d$. at 778. 
have included a variable to reflect the the individual's academic department in order to account for the possibility that women were concentrated in fields for which there was little demand..$^{75}$

With respect to the inclusion of post-hire productivity factors, such as quantity of publications and quality of teaching, the court agreed with plaintiffs that sex discrimination may have restricted the opportunities open to women to "produce" in the first place. Consequently, any attempt to include variables measuring faculty members' accomplishments while at CUNY might "incorporate the effects of discriminatory decisions rather than provide an independent measure of . . . productivity." "78 In other words, a regression analysis need not include any productivity variables that might be influenced by the employer's (possibly discriminatory) actions. As to pre-hire productivity measures, the court found that such factors were already taken into account by other variables, including age, highest degree, years between degree, and the quality of the institution granting the degree. ${ }^{77}$

The most striking aspect of the court's position here is its "Catch-22" response to the issue of post-hire productivity. After all, the plaintiffs were only alleging that the university had been guilty of intentional sex discrimination. Is it appropriate for the court, in effect, to presume that post-hire productivity variables would be tainted, so that they need not be taken into account?

An alternative, more sensible interpretation of Melani is that the court was not rejecting defendant's explanations outright, but was simply saying that, because of possible pitfalls in the variables that defendant would invoke, an inference of discrimination $c a n$ be drawn on the basis of plaintiffs' study, even though these variables are omitted. Defendant may introduce its own study, taking such factors into account, to rebut the inference that plaintiffs want the court to draw. As far as it goes, this response is sound-a court's conclusion that a prima facie case of discrimination has been made out should be a matter of sound discretion since data will almost always admit of further refinement and no formula can dictate where the line must be drawn.

But this response justifies the imposition of this "Catch 22" on

78 Id. at 779.

76 See id. at 778 ("For example, as a result of discrimination, a woman may be assigned greater teaching responsibilities than a similarly situated man. Her ability to do research, her teaching performance and her time for administrative work all may suffer as a result of the initial discriminatory assignment.").

77 Id. at 778-79. There is, however, no reason to believe that these factors truly capture the productivity factors with which the university would be concerned. 
the defendant only so long as the court refrains from imposing the same "Catch 22" upon the defendant's rebuttal. Suppose defendant introduced its own study, showing that the otherwise unexplained difference in compensation could be explained by such factors as publications, quality of teaching, committee work, and community service. Would this rebuttal evidence be subject to outof-hand refutation on the same argument that prevented it from defeating the prima facie case? Specifically, might not defendant's rebuttal be rejected unless it controlled for teaching load and other factors that affect productivity ${ }^{78}$ but that may be tainted by discrimination?

Even if these productivity variables, when controlled for illicit influences, explain the differences in average salary, there may be problems with the measurement of the variables themselves. For example, if the quality of teaching is measured by the esteem of faculty colleagues, then this variable is potentially tainted by discrimination, for faculty colleagues are as subject as anyone else to discriminatory attitudes and one should not defer to "coworker preference." If the quality rating is based on systematic student evaluations of teacher performance, it may be objected that student evaluations are also "tainted" and that their use thus amounts to an impermissible deference to "customer preference."

Furthermore, if it turned out that the higher productivity of male faculty members was indeed due, for example, to the greater teaching load of female faculty members, then the university could not use productivity to explain the salary differential. Nevertheless, the university might try to justify the differential by stating that it values publications and other productivity factors over volume of teaching.

But a court may question the legitimacy of the employer's valuation of teaching volume relative to other productivity factors. Once a court concludes that employees are performing "equal work," it might not allow an employer to pay people differently on the basis of essentially marginal differences. Even a court that concludes that an employer may pay a premium to those faculty members who, for example, publish more and teach less will wonder

78 For example, an individual who does more teaching will have less time to publish or to participate in university governance or outside community service.

${ }^{2}$ Cf. 29 C.F.R. § 1604.2(a)(1)(iii) (1983) ("bona fide occupational qualification" exception of Title VII not applicable to a "refusal to hire an individual because of the preferences of coworkers").

${ }^{80} \mathrm{Cf}$. id. ("bona fide occupational qualification" exception of Title VII not applicable to a "refusal to hire an individual because of the preferences of . . . customers"). 
whether the difference in teaching loads between men and women is attributable to sex discrimination. An evaluation of this question would once again involve the twists and turns that we have been describing. In fact, once this mode of inference-drawing is let loose, it is possible to imagine it continuing indefinitely in an unbounded cascade of proffered explanations and "Catch 22 " objections.

The second remarkable aspect of Melani concerns the university's objection to plaintiffs' statistical study on the ground that it failed to include an "academic department" variable. The university argued that salary differences might be attributable to the fact that women tend to be concentrated in fields for which there is less demand..$^{81}$ The court rejected this argument, observing that even the defendant's own expert had omitted from his study any measurement of academic department "because inclusion of such factors would not yield a statistically significant improvement in his model due to the large number of departments."82 Furthermore, the court stated that "Title VII regression studies . . . need not account for every factor that conceivably might explain differences in salaries or promotions. Consequently, the omission of a variable for academic department does not negate the probative value of the studies."Bs

The court's response is troubling. While a court's decision to consider that a prima facie case has been made out should be left to its sound discretion, the court in Melani appears to have abused this discretion. A plaintiff needs to make a showing that passes some threshold of plausibility before a burden of explanation should be shifted to the defendant; it seems to us plainly wrong to suggest that a study that treats French teachers and teachers of computer science as fungible for purposes of making out a prima facie case of salary discrimination in a university satisfies this requirement of threshold plausibility. Moreover, it is one thing to

Melani, 561 F. Supp. at 779.

az Id. At first blush, it is difficult to see why taking academic departments into account would not have yielded statistically significant improvements in defendant's study. Perhaps if each department of each component school of the university were considered to be a separate department, there would be too few employees in any particular department to produce statistically significant results. But a reasonable aggregation of the data might have cured this defect. For example, all the teachers in the French departments of various schools could be aggregated together in one cohort. And if small numbers were still a problem, all the teachers of non-English language and literature could be the cohort. Moreover, without information concerning the overall design of defendants' study, it is hard to know whether the fact that a departmental variable would not improve that study suggests that the inclusion of such a variable would not improve the power of the plaintiffs' study.

as. (citations and footnote omitted). 
shift a burden to a defendant when its effect is merely to require the defendant to proffer available evidence. It is quite another thing to shift a burden to the defendant when it has already been decided that the burden will be insurmountable. Once the court in Melani assumed that the laws of statistics would render a departmental variable useless, it seems particularly wry to transfer the costs of this uncertainty to the defendant in light of the facial implausibility of the plaintiffs' statistical case in the absence of this variable.

One explanation for the court's willingness to render judgment for the plaintiff in the absence of information concerning the amount of the salary variance attributable to different fields of faculty endeavor is that Melani was brought under Title VII, which is not subject to the "equal work" limitation of the Equal Pay Act. ${ }^{84}$ But it is not clear under what circumstances a Title VII wage-discrimination claim may be brought when equal work is not involved, especially since the Supreme Court has avoided the issue of whether Title VII implicitly embodies the doctrine of comparable worth. ${ }^{85}$

Is Melani a case that could have been successfully brought under the Equal Pay Act? The court did not directly address this issue, but it is possible to characterize the job of an associate professor of English, for example, as "equal work" in comparison with that of an associate professor of physics. The two professors hold the same rank, and they are both required to meet classes, grade exams, produce original scholarship, and participate in the governance of their institution. And yet, if one chooses to emphasize the factors that distinguish the two jobs, it will not be hard to show that, far from being substantially equal, the two jobs are quite different. It is not our purpose to comment upon the propriety of a conclusion that Melani involved "equal work"; it suffices to say that if Melani does involve equal work, there is a rather heavy dose of "comparable worth" already in place under the Equal Pay Act. If, however, Melani does not involve "equal work," then it is a case in which an employer was found in violation of Title VII for failing to pay equal compensation to employees performing work of comparable value.

s4 County of Washington v. Gunther, 452 U.S. 161, 168-80 (1981).

ss See id. at 166. 


\section{CONCLUSION}

There is widespread opposition to the theory of "comparable worth," and the theory has not explicitly been made a part of American employment discrimination law. Yet, implementing the Equal Pay Act principle of "equal pay for equal work" requires the use of many of the same principles that provoke this opposition. When one starts with the suspicion that discrimination, and not rational decisionmaking, is at the heart of employment decisions, a prima facie case of discrimination is easy to establish, and an employer is placed in a "Catch-22" situation where almost any proffered justification for the decision is seen instead as incriminating. Because the Equal Pay Act is an established part of American law, this legal state of affairs may be unalterable. We suggest, however, that once the underlying nature of Equal Pay Act claims is apparent, the desirability of such legal rules, far from being a foregone conclusion, is an open question. 